\title{
Increasing cell biomass in Saccharomyces cerevisiae increases recombinant protein yield: the use of a respiratory strain as a microbial cell factory
}

\author{
Cecilia Ferndahl'1, Nicklas Bonander22, Christel Logez³, Renaud Wagner³, Lena Gustafsson'1, Christer Larsson'1, \\ Kristina Hedfalk4 ${ }^{4}$ Richard AJ Darby² and Roslyn M Bill*2
}

\begin{abstract}
Background: Recombinant protein production is universally employed as a solution to obtain the milligram to gram quantities of a given protein required for applications as diverse as structural genomics and biopharmaceutical manufacture. Yeast is a well-established recombinant host cell for these purposes. In this study we wanted to investigate whether our respiratory Saccharomyces cerevisiae strain, TM6*', could be used to enhance the productivity of recombinant proteins over that obtained from corresponding wild type, respiro-fermentative strains when cultured under the same laboratory conditions.

Results: Here we demonstrate at least a doubling in productivity over wild-type strains for three recombinant membrane proteins and one recombinant soluble protein produced in TM6* cells. In all cases, this was attributed to the improved biomass properties of the strain. The yield profile across the growth curve was also more stable than in a wild-type strain, and was not further improved by lowering culture temperatures. This has the added benefit that improved yields can be attained rapidly at the yeast's optimal growth conditions. Importantly, improved productivity could not be reproduced in wild-type strains by culturing them under glucose fed-batch conditions: despite having achieved very similar biomass yields to those achieved by TM6* cultures, the total volumetric yields were not concomitantly increased. Furthermore, the productivity of TM6* was unaffected by growing cultures in the presence of ethanol. These findings support the unique properties of $\mathrm{TM}^{*}$ as a microbial cell factory.

Conclusions: The accumulation of biomass in yeast cell factories is not necessarily correlated with a proportional increase in the functional yield of the recombinant protein being produced. The respiratory S. cerevisiae strain reported here is therefore a useful addition to the matrix of production hosts currently available as its improved biomass properties do lead to increased volumetric yields without the need to resort to complex control or cultivation schemes. This is anticipated to be of particular value in the production of challenging targets such as membrane proteins.
\end{abstract}

\section{Background}

The development of recombinant protein production systems that can be applied to a wide range of targets is a key area of research. This is particularly true for the production of membrane proteins, which are high value targets in the drug discovery pipeline, and which cannot yet be produced in high yields in a predictable manner. Grisshammer and Tate first addressed these issues in 1995 in their review of the challenges of producing recombinant

\footnotetext{
* Correspondence: r.m.bill@aston.ac.uk

2 School of Life and Health Sciences, Aston University, Aston Triangle, Birmingham B4 7ET, UK

Full list of author information is available at the end of the article
}

membrane proteins [1]. While more recent articles have individually covered the use of bacteria [2-5], yeasts [6], insect cells [7], mammalian cells [8] and cell-free systems [9] as production hosts [10,11], it is apparent that generic solutions are still not forthcoming and that the way forward should be through a rationalization of the science of protein production [12-14].

Yeast species, especially Pichia pastoris and S. cerevisiae $[6,11,15,16]$ have already been identified as one of the most important components of a matrix of protein production hosts [12], and have contributed a substantial number of recombinant eukaryotic membrane proteins 
that have enabled high resolution structure determination [17-20]. We and others [21-23] have recently started to take a more systematic approach [14] to optimise $S$. cerevisiae as a host cell for recombinant protein production. In general, a sequenced genome and well-understood expression vectors with a range of promoters and expression tags make this yeast species an attractive and flexible option. While the P. pastoris system has a much smaller set of vectors available and a less-well-established molecular biology, it can be cultured to very high densities [24] potentially producing large quantities of the protein of interest. Recently we examined factors, including pre-induction cellular biomass, affecting the total yield of recombinant green fluorescent protein (GFP) in P. pastoris [25], and noted the benefits of this as a strategy to improve productivity. While this approach is generally accepted to be a useful way to boost the yields of soluble proteins, it is well established that the accumulation of biomass does not necessarily lead to a correlated increase in membrane protein yield [21] and in the case of G protein-coupled receptors (GPCRs), specific activity is often lower [26]. Indeed, it has been noted that higher cell densities can generate cellular stresses leading to modifications in membrane composition [27] and that this modified environment influences the activity of recombinant proteins. Consequently, medium cell density fermentation procedures for GPCR expression in P. pastoris have been suggested to be preferable to ones where biomass yields are maximised [26].

Here we examined a respiratory strain of S. cerevisiae, $\mathrm{TM}^{*}$, which generates substantially higher biomass yields than wild-type at the expense of ethanol formation $[28,29]$. We asked whether this strain could be used as a tool to generate improved volumetric yields of functional proteins, especially membrane proteins. Since this strain has an engineered phenotype, we anticipated that this might mitigate against the cellular stress associated with biomass accumulation in wild-type strains. In the TM6* strain, glucose uptake is solely dependent on a chimeric hexose transporter mediating reduced sugar uptake: the strain was generated by integrating the gene encoding the chimeric hexose transporter, Tm6*, into the genome of a hexose transporter null yeast. While oxygen depletion commonly controls the switch from respiration to fermentation, in wild-type $S$. cerevisiae this switch also occurs in response to the external glucose concentration. The TM6* strain shows a fully respiratory metabolism even at high glucose levels as seen for aerobic organisms due to the characteristics of its chimeric hexose transporter. It therefore switches to fermentation only when oxygen is limiting.

In this study, the effectiveness of the TM6* strain as a microbial cell factory was tested using three challenging membrane protein targets: the eukaryotic glycerol trans- port facilitator, Fps1 [30,31] and two recombinant human GPCRs (the $\mathrm{A}_{2 \mathrm{a}}$ adenosine receptor $\left(\mathrm{A}_{2 \mathrm{a}} \mathrm{R}\right)$ and the cannabinoid receptor 2 (CNR2)); as well as soluble GFP. Our start point was to examine TM6* under conditions that we had previously shown to give maximum recombinant Fps1 yield for the corresponding wild-type [21] and to compare this with the yield obtained under optimal growth conditions. Therefore TM6* cells were cultured at $20^{\circ} \mathrm{C}, \mathrm{pH} 5$ and $30^{\circ} \mathrm{C}, \mathrm{pH} 5$, respectively. Our data show at least a doubling in productivity over wild-type strains for all these proteins when they are produced in TM6* cells. In all cases, this was attributed to the improved biomass properties of the strain. The yield profile across the growth curve was also found to be more stable than in the wild-type strain, and was not further improved by lowering culture temperatures to $20^{\circ} \mathrm{C}$, which is commonly found for wild-type strains [21]. This has the added benefit that improved yields can be attained rapidly at the yeast's optimal growth conditions. This improved productivity could not simply be reproduced in a wild-type strain by culturing it under glucose fed-batch conditions prior to glucose exhaustion. Likewise, the productivity of TM6* was unaffected by culturing it in the presence of ethanol.

To conclude, the beneficial properties of TM6* appear to be unique. Consequently, TM6* should prove to be a useful addition to the matrix of production hosts at the disposal of modern structural biology projects, especially for challenging targets such as membrane proteins: we suggest that transfer of expression plasmids from wildtype strains into TM6* is a simple way to at least double the yield of a range of recombinant proteins.

\section{Results}

We have previously demonstrated that Fps1 is a challenging eukaryotic membrane protein target that can only be produced in low yields in a variety of hosts (Table 1). Subsequently, we demonstrated that for wild-type S. cerevisiae the best yields were achieved when the culture temperature was decreased from $30^{\circ} \mathrm{C}$ to $20^{\circ} \mathrm{C}$ and the cells were harvested at a precise time point [21]. In this study, we explored whether increasing the biomass yield of $S$. cerevisiae cultures by simply switching to the respiratory $\mathrm{TM}^{*}$ strain under the same culture conditions could be an alternative strategy to improve productivity.

Fps 1 can be produced in TM6* at the same yield per unit of total membrane protein as two wild-type strains

We analysed the production of recombinant Fps1 in TM6*, which has improved biomass production properties [29], and compared it to production under identical culture regimes in two typical wild-type strains: the wildtype, respiro-fermentative 954 VW K70 and KOY.PK21 C82 strains of S. cerevisiae. The former strain was used 
Table 1: Fps 1 can be produced in a range of microbial cell factories

\begin{tabular}{|c|c|c|c|c|}
\hline Production Host & Promoter & Production & Localisation & Reference \\
\hline S. cerevisiae W301-1A & GAL1 & Yes & $\mathrm{tm}$ & [38] \\
\hline S. cerevisiae W301-1A & TPI1 & Yes & $\mathrm{tm}$ & [38] \\
\hline S. cerevisiae 954 VW K70 & TPI1 & Yes & $\mathrm{tm}$ & [21] and this study \\
\hline S. cerevisiae KOY.PK2-1C82 & TPI1 & Yes & $\mathrm{tm}$ & This study \\
\hline S. cerevisiae TM6* & TPl1 & Yes & $\mathrm{tm}$ & This study \\
\hline P. pastoris X-33 & $A O X 1$ & Yes & $\mathrm{pm}$ & [38] \\
\hline P. pastoris X-33 & $A O X 1$ & Yes $^{\dagger}$ & nd & [38] \\
\hline P. pastoris GS115 & $A O X 1$ & Yes & nd & [38] \\
\hline P. pastoris KM71 & $A O X 1$ & Yes & nd & [38] \\
\hline E. coli JM109 & lac & Yes & $\mathrm{tm}$ & [38] \\
\hline E. coli JM109 & $\mathrm{T} 7 / \mathrm{lac}$ & Yes & $\mathrm{tm}$ & [38] \\
\hline
\end{tabular}

Fps1 was produced in S. cerevisiae, $P$. pastoris and $E$. coli as previously described $[21,38]$ and as a part of this study (tm, total membrane; pm, plasma membrane; nd, not determined). Note that ${ }^{\dagger}$ indicates that the $a$-factor signal peptide was used in the expression construct. In all cases prior to this study, total yields were less than $50 \mu \mathrm{g} / \mathrm{L}$, which was below the threshold value for further study $[21,38]$.

in our previous study [21] and the latter is derived from CEN.PK2-1C, which is the genetic background of TM6*. The yield of Fps1 per unit of total membrane protein was quantified by densitometry of immunoblot signals from $75 \mu \mathrm{g}$ total membrane protein. For quantifying Fps1 in crude cell extracts, signals from $35 \mu \mathrm{g}$ total cell extract protein were used. All signals were normalised to our previously-described internal standard [21]. Table 2 shows that when cultured at $30^{\circ} \mathrm{C}, \mathrm{pH} 5$, all three hosts gave the same average yield per unit of total membrane protein.

On reducing the temperature of the recombinant TM6* cultures to $20^{\circ} \mathrm{C}$, we noted no statistically significant improvement in their productivity (data not shown). This is in contrast to the commonly-observed increase in yield seen on lowering culture temperatures in wild-type yeast $[21,32]$, as well as other recombinant hosts $[14,33]$. The gas profiles (Figure 1) were similar for both $20^{\circ} \mathrm{C}, \mathrm{pH} 5$ and $30^{\circ} \mathrm{C}$, pH5 and showed only one phase of growth: the small amounts of ethanol produced did not result in a biphasic growth curve. The generation times calculated under these conditions were 5.5 (standard error of the mean, SEM: 0.5$) \mathrm{h}$ and $2.9(0.1) \mathrm{h}$ at $20^{\circ} \mathrm{C}$ and $30^{\circ} \mathrm{C}$, respectively. The duration of the glucose phase was significantly longer for the $20^{\circ} \mathrm{C}$ culture $(64.3(9.5) \mathrm{h}) \mathrm{com}-$ pared with that for $30^{\circ} \mathrm{C}(27.0(2.9) \mathrm{h})$, as expected. These temperature-dependent data are consistent with our previously-reported growth characteristics for a wild-type strain [21]. We also noted that the lag phase for the $20^{\circ} \mathrm{C}$ cultures was much more variable than for the $30^{\circ} \mathrm{C}$ cultures (data not shown). Ethanol analysis revealed a maximum yield of $0.03(0.02) \mathrm{g} \mathrm{g}^{-1}$ consumed glucose at $20^{\circ} \mathrm{C}$ and $0.07(0.02) \mathrm{g} \mathrm{g}^{-1}$ at $30^{\circ} \mathrm{C}$, compared with a typical value of $0.3 \mathrm{~g} \mathrm{~g}^{-1}$ for a wild-type strain at $30^{\circ} \mathrm{C}$. The maximum glucose consumption rate was more than doubled

Table 2: Recombinant Fps 1 yields per unit of total membrane protein are identical for two wild-type S. cerevisiae strains and respiratory TM6*

\begin{tabular}{|c|c|c|c|c|}
\hline \multirow[b]{2}{*}{ Strains } & \multicolumn{3}{|c|}{ Fps 1 yield expressed as a mean densitometry signal } & \multirow[b]{2}{*}{ Stationary phase } \\
\hline & All samples & Glucose phase & Ethanol phase & \\
\hline 954 VW K70 & $3.3(0.3 ; n=2)$ & $3.2(0.1 ; \mathrm{n}=2)$ & $3.5(0.9 ; \mathrm{n}=2)$ & $2.6(0.8 ; n=2)$ \\
\hline KOY.PK2-1C82 & $3.7(0.6 ; n=3)$ & $3.7(0.6 ; n=3)$ & $3.7(0.9 ; n=3)$ & $2.5(0.9 ; \mathrm{n}=3)$ \\
\hline TM6* & $3.1(0.7 ; \mathrm{n}=3)$ & $3.2(0.8 ; n=3)$ & - & $2.4(0.9 ; n=3)$ \\
\hline
\end{tabular}

Immunoblots were performed and quantified on membrane-bound fractions from two wild-type cultures and the TM6* strain, producing recombinant Fps1. The values given are mean densitometry signals related to our internal standard as described in the Methods section. Standard error of the mean, in parentheses, was calculated for replicate cultures as indicated. Note that there is no significant yield improvement per unit of total membrane protein for production in $\mathrm{TM}^{*}$ compared with these wild-types: increased yield is achieved on account of improved biomass production in TM6* (see Figure 2). Note also that since TM6* does not have an ethanol phase (-), the "stationary phase" samples were harvested at least $10 \mathrm{~h}$ after glucose exhaustion. 


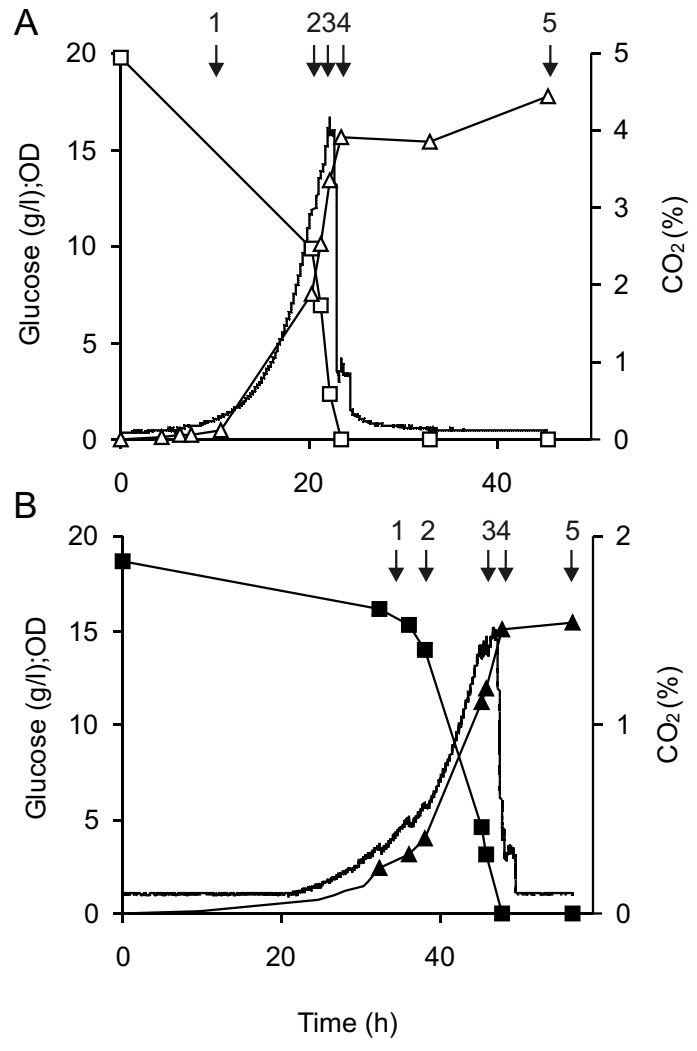

Figure 1 Culture profiles for TM6* transformants grown aerobically on $2 \%$ glucose. Cells were cultured at (A) $30^{\circ} \mathrm{C}, \mathrm{pH} 5$ and (B) $20^{\circ} \mathrm{C}, \mathrm{pH}$ 5. Glucose concentration (squares), $\mathrm{OD}_{610}$ (triangles) and $\mathrm{CO}_{2}$ level (no symbol) versus time is shown for growth under these conditions. The sampling points are indicated with an arrow, and each sample is also given a number for ease of identification.

on changing the temperature from $20^{\circ} \mathrm{C}$ to $30^{\circ} \mathrm{C}$ with rates of $2.0(0.3)$ and $5.1(0.6) \mathrm{mmol}$ (glucose) $\mathrm{g}^{-1}$ (dry weight) $\mathrm{h}^{-1}$, respectively.

\section{Total volumetric yields of Fps 1 from wild-type strains can be more than doubled in TM6* due to its improved biomass yield}

When the biomass of the cultures was taken into account, improved volumetric yields for TM6* were clearly apparent compared with wild-type cells (Figure 2). At $30^{\circ} \mathrm{C}, \mathrm{pH}$ 5 , yields per unit of total membrane protein from glucose-phase cells (at harvest points 1-3) showed more than a 2-fold increase when comparing TM6* with wild-type (mean values were 16.3 and 7.8 respectively; Figure 2B). This meant that the doubling in yield we had previously obtained by lowering the temperature of wild-type cultures from $30^{\circ} \mathrm{C}$ to $20^{\circ} \mathrm{C}$ [21] had now been exceeded by switching to the $\mathrm{TM}^{*}$ strain and culturing at $30^{\circ} \mathrm{C}$. Essentially, the highest yields were now being produced under the optimal growth conditions: more Fps1 is produced more quickly in TM6* (generation time $2.9 \mathrm{~h}$

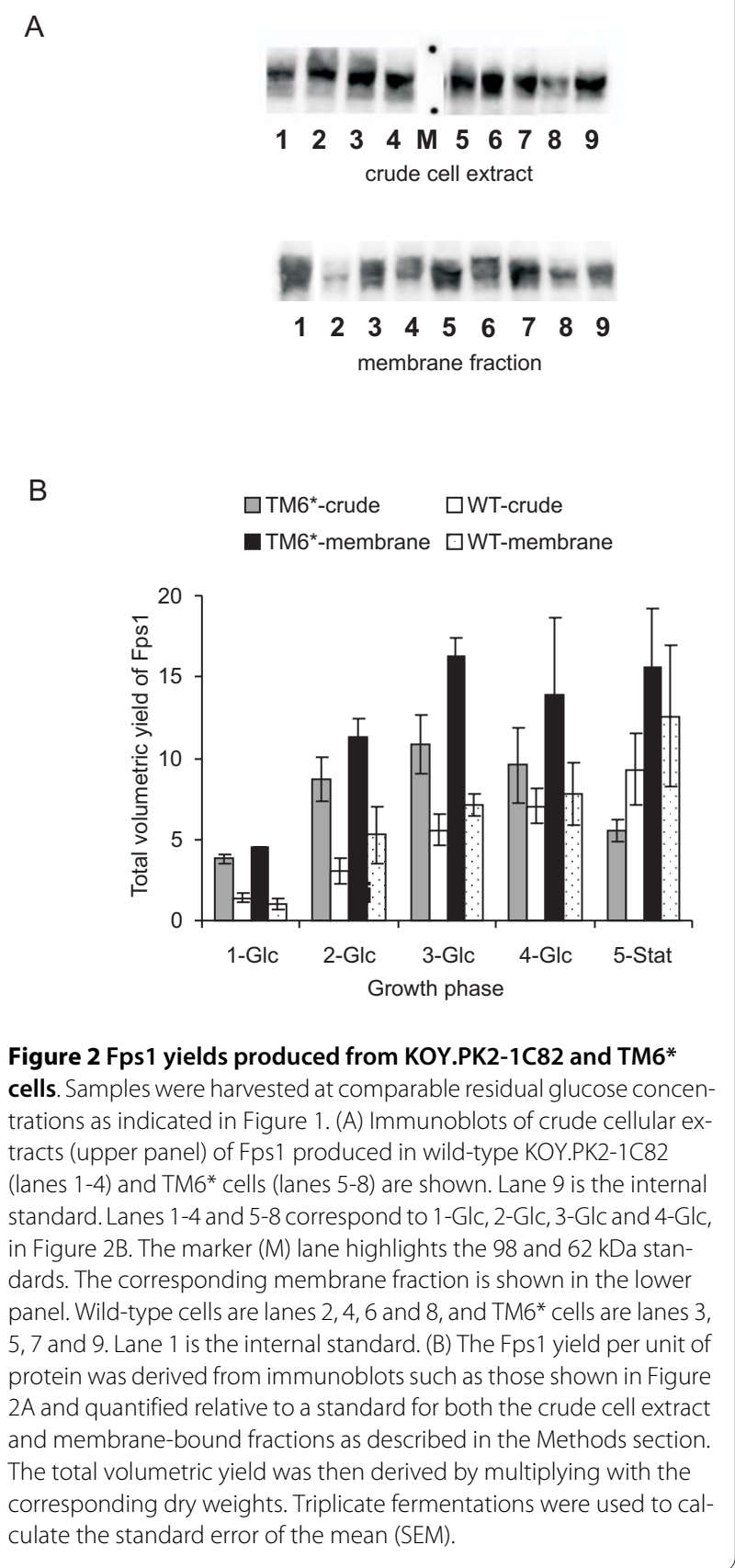

(SEM: 0.1)) than in the previously-optimised wild-type cultures at $20^{\circ} \mathrm{C}$ (generation time $8.9 \mathrm{~h} \mathrm{[21]).}$

\section{Improved Fps 1 yields in TM6* cannot be reproduced by} culturing wild-type strains under glucose fed-batch conditions prior to glucose exhaustion

In an attempt to improve biomass yields for the wild-type strain and thereby obtain improved volumetric yields as seen in the TM6* cultures, the wild-type strain $954 \mathrm{VW}$ $\mathrm{K} 70$ was cultured at $30^{\circ} \mathrm{C}, \mathrm{pH} 5$ with $1 \%$ glucose until the glucose was depleted and then grown under glucose fedbatch conditions. This was done in order to determine 
whether manipulating the culture regime to extend the glucose phase of the wild-type strain would produce higher amounts of Fps1. The substrate was fed to the culture at a rate of $2 \mathrm{~g} \mathrm{~L}^{-1} \mathrm{~h}^{-1}$ to a final concentration of $2 \%$ glucose (w/v). Figure 3A shows the profile of $\mathrm{CO}_{2}$ production, glucose consumption and $\mathrm{OD}_{610}$, which was as anticipated: $\mathrm{CO}_{2}$ production is essentially constant during the glucose feed with the ethanol being respired immediately after the glucose feed is finished, which is seen from the second $\mathrm{CO}_{2}$ peak. Figure 3B shows that the yield of Fps1 per unit of total membrane protein was neither sustained nor increased during the fed-batch. On the contrary, the yield decreased with the onset of the fedbatch, indicating that by essentially extending the glucose growth phase, the total volumetric yield from wild-type cells was not improved: despite having achieved very similar biomass yields to those achieved by TM6" cultures (Figure 1), the total volumetric yields were not concomitantly increased. It was therefore clear that the simple manipulation of culture conditions for a wild-type strain could not mimic the properties of TM6*.

\section{Fps 1 yields in TM6* are unaffected by growing cultures in} the presence of ethanol

We next investigated whether yields from respiratory TM6* cells would return to wild-type levels in the presence of ethanol. TM6* was therefore cultured at $30^{\circ} \mathrm{C}, \mathrm{pH}$ 5 in the presence of $2 \%$ glucose and $7 \mathrm{~g} \mathrm{~L}^{-1}$ ethanol to simulate the levels observed in wild type strains. Figure $4 \mathrm{~A}$ shows that the ethanol concentration was essentially constant through the glucose consumption phase, indicating that the TM6* cells grew on glucose without any substantial consumption of ethanol. At the point of glucose depletion, the cells started to grow on the ethanol immediately which is seen by the second $\mathrm{CO}_{2}$ peak and the sustained increase in biomass. The total volumetric yield of Fps1 in the cultures to which ethanol had been added was higher than those without ethanol on account of their higher biomass yields (Figure 4B). It was clear however, that addition of ethanol to TM6* cultures did not result in wild-type yields at the corresponding growth phase (Fig 2).

\section{Functional yields of two human GPCRs and soluble GFP are also increased when produced in TM6* compared with wild-type S. cerevisiae}

Having improved the yield of Fps1 in our respiratory $S$. cerevisiae strain, we wished to verify that the yields of other recombinant proteins would also be increased compared to wild-type. We therefore produced the human GPCRs, $\mathrm{A}_{2 \mathrm{a}} \mathrm{R}$ and CNR2, in TM6* at $30^{\circ} \mathrm{C}$ (Figure 5). This resulted in a doubling of the wet cell mass in $\mathrm{TM}^{*}(9 \mathrm{~g}$ and $10 \mathrm{~g}$, respectively; Table 3) compared with wild-type cells ( $5 \mathrm{~g}$ and $4 \mathrm{~g}$, respectively; Table 3 ) and an increase by

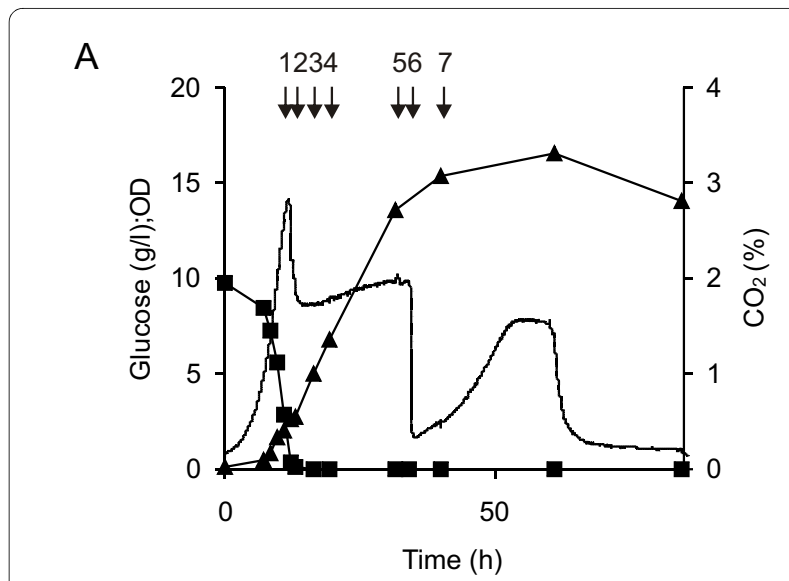

B
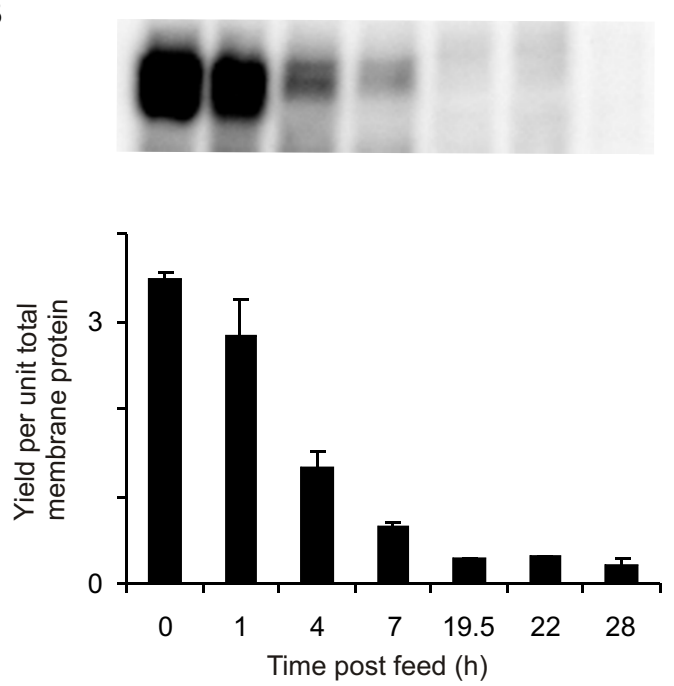

Figure 3 Analysis of protein yields for a wild-type strain grown under glucose fed-batch conditions in an attempt to mimic TM6* (A) $\mathrm{CO}_{2}$ production (no symbol), glucose consumption (squares) and $\mathrm{OD}_{610}$ (triangles) show classic profiles for a fed-batch culture. Arrow 1 indicates the onset of the feed ( $0 \mathrm{~h}$ ) and arrow 6 the end ( $22 \mathrm{~h}$ ). (B) An immunoblot (upper panel) showing the Fps1 production at 0, 1, 4, 7 , 19.5, 22 and $28 \mathrm{~h}$ after the onset of the feed: its quantitation (lower panel) is related to the internal standard.

at least a factor of 4 in the corresponding total membrane protein yield (5.1 $\mathrm{mg}$ and $5.8 \mathrm{mg}$ to $23.3 \mathrm{mg}$ and $29.4 \mathrm{mg}$, respectively; Table 3 ). Radioligand binding experiments for $\mathrm{A}_{2 \mathrm{a}} \mathrm{R}$ yielded respective $\mathrm{B}_{\max }$ and $\mathrm{K}_{\mathrm{d}}$ values of 5.12 (SEM: 0.59) pmol mg-1 and 5.52 (1.68) $\mathrm{nM}$ for wild-type membranes compared with $5.16(0.61) \mathrm{pmol} \mathrm{mg}^{-1}$ and 6.26 (1.86) nM for TM6* membranes. The corresponding values for CNR2 were 22.02 (4.00) pmol mg-1 and 39.75 (12.96) $\mathrm{nM}$ for wild-type membranes and 17.02 (2.20) pmol $\mathrm{mg}^{-1}$ and 30.81 (7.71) $\mathrm{nM}$ for TM6* membranes. These data illustrate that the yield of recombinant GPCR per unit of total membrane protein is unchanged in the TM6* strain, while the total functional protein yield is at 
A

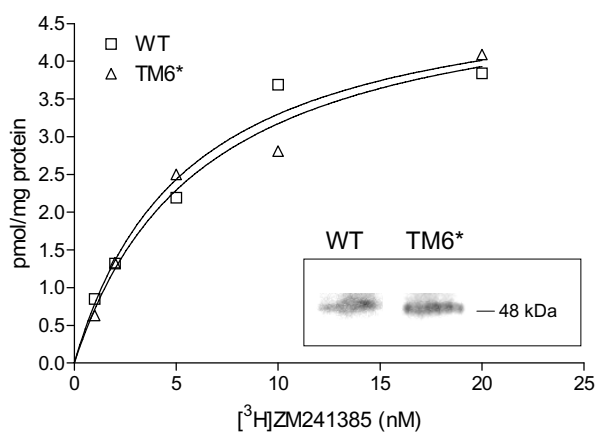

B

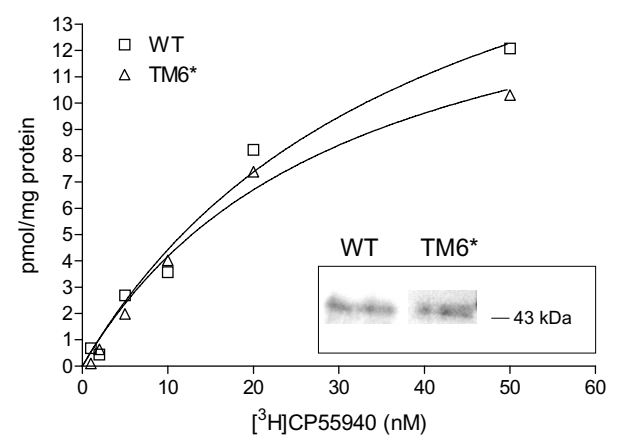

Figure 5 Saturation ligand binding to membrane preparations of wild-type and TM6* cells producing human GPCRs. (A) Labelled and unlabelled ZM241385 ligands were incubated for 60 min at $25^{\circ} \mathrm{C}$ with $10 \mu \mathrm{g}$ cell membrane containing recombinant human $\mathrm{A}_{2 \mathrm{a}} \mathrm{R}$. (B) Labelled and unlabelled CP55940 ligands were incubated for 90 min at $30^{\circ} \mathrm{C}$ with $10 \mu \mathrm{g}$ cell membrane containing recombinant human CNR2. Saturation binding curves were analysed by nonlinear regression using Prism Software (GraphPad Software, USA) to calculate $B_{\max }$ and $K_{d}$. The immunoblot signals for the corresponding proteins are shown as insets within the binding curves.

membrane-protein-specific consortia have been established such as E-MeP, MePNet, EDICT and others [34]. Typical activities include high-throughput production of large numbers of membrane proteins, especially GPCRs [35]. Such projects are slowly making important contributions to our understanding of the structural biology of membrane proteins (see http://blanco.biomol.uci.edu/ Membrane Proteins xtal.html), but by their very nature there is a high attrition rate as individual proteins fail to be produced using high-throughput strategies.

A current and very encouraging trend is to consider membrane protein production as a scientific problem that must be systematically and rationally addressed [1214]. We and others have contributed to this using yeast $[21,22]$, which has been the production host for a substantial number of recombinant eukaryotic membrane proteins to date. As it is often desirable to obtain struc-

\section{Discussion}

Structural genomics projects have undertaken the important task of characterising the hundreds of proteins that are encoded by organismal genomes. Most recently, 
Table 3: Total functional yields from TM6* producing two human GPCRs are at least quadruple that from the corresponding wild-type transformants

\begin{tabular}{cccccccc}
\hline Transformants & $\begin{array}{c}\text { Duration of } \\
\text { culture }(\mathbf{h})\end{array}$ & $\begin{array}{c}\text { Specific } \\
\text { growth } \\
\text { rate }(\mathbf{h}-\mathbf{1})\end{array}$ & $\begin{array}{c}\text { Dry cell } \\
\text { weight yield } \\
\mathbf{( g ~ g - 1 ~ G l c )}\end{array}$ & $\begin{array}{c}\text { Harvest wet } \\
\text { cell weight (g) }\end{array}$ & $\begin{array}{c}\text { Total } \\
\text { membrane } \\
\text { protein yield } \\
\text { (mg) }\end{array}$ & $\begin{array}{c}\text { Bmax } \\
\text { (pmol mg-1) }\end{array}$ & Kd (nM) \\
\hline WT CNR2 & 16 & $0.3(0.03)$ & $0.12(0.02)$ & 5.0 & $5.1(0.48)$ & $22.02(4.00)$ & $39.75(12.96)$ \\
WT A ${ }_{2 a} R$ & 16 & $0.3(0.03)$ & $0.12(0.02)$ & 4.0 & $5.8(0.19)$ & $5.12(0.59)$ & $5.52(1.68)$ \\
TM6 $^{*} \mathrm{CNR2}$ & 25 & $0.2(0.02)$ & $0.32(0.02)$ & 9.0 & $23.3(1.00)$ & $17.02(2.20)$ & $30.81(7.71)$ \\
$\mathrm{TM}^{*} \mathrm{~A}_{2 \mathrm{a}} \mathrm{R}$ & 25 & $0.2(0.02)$ & $0.32(0.02)$ & 10 & $29.4(0.98)$ & $5.16(0.61)$ & $6.26(1.86)$ \\
\hline
\end{tabular}

The human GPCRs, $A_{2 a} R$ and CNR2, were produced in the wild-type S. cerevisiae strain, BY4741 (WT), and the respiratory strain, TM6*. Cells were harvested at the time points indicated for preparation of membranes for functional analysis, as described in the Methods section. The mean growth rate $\left(h^{-1}\right)$ is calculated for the exponential growth phase $(n=2)$. The mean dry cell weight yield is reported with respect to the glucose consumed $(n=2)$. Harvest wet cell weight is reported in $g$, and the mean total membrane protein yield from these cells is reported $(n=3)$. $B_{\max }$ and $K_{d}$ values were calculated from the curves shown in Figure $5(n=3)$. In all cases the standard error of the mean is given in parentheses.

tural and functional data on a specific protein, such as a key drug target or an individual member of a biological pathway, this absolutely warrants a systematic, tailored approach. In our own work, we initially focused on the glycerol facilitator from S. cerevisiae - Fps1 - on which we have amassed a body of in vivo structure-activity data $[30,31,36,37]$. Despite having constructed a good understanding of the gating mechanism of this intriguing protein, the ability to produce it in amounts sufficient for structural studies has remained elusive [38] (Table 1). In this study we therefore examined production yields in a respiratory S. cerevisiae strain, TM6*, with improved biomass-producing properties [29].

We found that the best Fps1 yield from previous studies in wild-type yeast [21] was maintained in the TM6* membrane in cultures grown at $30^{\circ} \mathrm{C}$ in batch. This is particularly advantageous since the best production conditions are now the optimal growth conditions and hence Fps1 can be produced more quickly in TM6* (generation time 2.9 (SEM: 0.1) h) than in previously-optimised wildtype cultures at $20^{\circ} \mathrm{C}$ (generation time $8.9 \mathrm{~h}$ ) [21]. For commercial applications, it is of utmost importance to avoid costs associated with cooling bioreactors and to minimise production times to maximise profit. Highthroughput platforms also significantly benefit from shorter generation times. The biggest benefit, however, was the total yield improvement resulting from the improved biomass properties of TM6* compared with the two wild-type strains without the need for complex cultivation regimes. In the glucose phase, maximum yields were achieved in both wild-type strains at an $\mathrm{OD}_{610}$ of 4.5 (0.1) during batch-growth with $2 \%$ glucose in the medium. When we produced Fps1 in the respiratory TM6* strain, however, maximum yields were obtained at an $\mathrm{OD}_{610}$ of 11.0 (1.5), a 2.4-fold increase in biomass over the wild-type. Consequently, the best yields of Fps1 from TM6* were more than 2-fold higher than the best yields from the wild-type strains. Interestingly, yields of Fps1 from TM6* were not further improved by lowering the temperature, in contrast to wild-type strains where this is routinely observed [21].

We were unable to improve yields of Fps1 in wild-type S. cerevisiae by extending the production phase prior to the diauxic shift (Figure 3) or to reduce yields in TM6* by growing cultures in the presence of ethanol, mimicking conditions found with wild-type yeast (Figure 4). We also found that the ethanol concentration was unchanged through the glucose consumption phase (Figure 4A) which indicated that the TM6* cells grew on glucose without co-consuming substantial amounts of ethanol. As soon as the glucose was depleted, the cells started to grow on the ethanol immediately which is seen by the second $\mathrm{CO}_{2}$ peak and continued biomass accumulation. We therefore concluded that the improved biomass properties of TM6*, which also enhanced the yields of three additional recombinant proteins, could not be achieved through simple manipulation of culture conditions.

In the related respiratory wine strain V5-TM6*P that we have also generated [39], the genes BIO2, BMS1, $M S D 1$ and RPO41 had a changed expression compared with the V5 parent [40] and were also correlated with improved protein yields in a wild-type strain [41]. This further strengthens our earlier observations that BMS1 plays a significant role in high yielding recombinant protein production [23]. Interestingly two subunits of the $26 \mathrm{~S}$ proteosome subunit, $R P T 1$ and $R P T 2$ are also down regulated in V5-TM6*P compared to V5 by a factor of 0.3 [40]. It is thus possible that the respiratory yeast phenotype has less protease activity than a wild-type strain 
which in turn negates the need to further slow the process by lowering the temperature.

Overall, it is clear that yeast cells are valuable production hosts on account of their potential for high volumetric yields, short generation times and affordable media formulations, especially in comparison with higher eukaryotic systems. Moreover, the ability to engineer strains with desirable properties that minimise stress responses is straightforward in yeast. In the case of an engineered strain such as TM6*, its improved biomass properties, which result from its respiratory phenotype, make it a particularly valuable resource for challenging proteins such as membrane proteins. For example, we report here the first production of functional human CNR2 in S. cerevisiae, and show that we can quadruple its yield by simply switching from a respiro-fermentative to a respiratory strain.

\section{Conclusions}

The TM6" phenotype provides a unique opportunity to improve recombinant protein production yields in S. cerevisiae through biomass accumulation. Enhanced volumetric yields were achieved for the yeast glycerol facilitator, Fps1, the human GPCRs, $\mathrm{A}_{2 \mathrm{a}} \mathrm{R}$ and CNR2, and a soluble GFP. The TM6* respiratory strain should therefore prove to be a useful addition to the matrix of production hosts at the disposal of modern structural biology projects, especially for challenging proteins.

\section{Methods \\ Plasmids}

The FPS1 gene was tagged at its 3 ' end with a sequence encoding the $\mathrm{HA}_{3}$ epitope to permit immunodetection; the carboxy-terminal threonine residue was replaced with the amino acid sequence: SGRIFYPYDVPDYAGYPYDVPDYAGYPYDVPDYAAQCGR. The $\mathrm{HA}_{3}$-tag sequence is underlined. The construct was expressed from the TPI promoter in the $2 \mu \mathrm{pYX} 212$ vector (Novagen; now discontinued) which contains the URA3 selection marker. The gene was cloned into the BamH1 and HindIII sites and the vector transformed into $S$. cerevisiae TM6*, KOY.PK2-1C82 and BY4741. For the S. cerevisiae 954 VW K70 strain the construct was expressed from the TPI promoter in the $2 \mu$ pYX222 vector (Novagen; now discontinued), which contains the HIS3 selection marker. Genes encoding human $A_{2 \mathrm{a}} \mathrm{R}$ and CNR2 receptors were tagged as above at the 3 ' end with the $\mathrm{HA}_{3}$-tag and at the 5 ' end with a sequence encoding the S. cerevisiae $\alpha$ factor secretion signal: MRFPSIFTAVLFAASSALAAPVNTT TEDETAQIPAEAVIGYSDLEGDFDVAVLPFSNSTNNG LLFINTTIASIAAKEEGVSLEKREAGS. The constructs were expressed from the TPI promoter in both the pYX212 and pYX222 vectors. The pCU426 GFP construct was the generous gift of Dr Arle Kruckeberg.

\section{Yeast strains and growth conditions}

The constructs cloned into plasmids pYX212 and pCU426 were transformed into S. cerevisiae strains KOYTM6*, referred to as TM6* [42], KOY.PK2-1C82 (MATa, ura 3-52, MAL 2-8c SUC2) [43] and BY4741 (MATa; his $3 \Delta 1$; leu $2 \Delta 0$; met15 $\Delta 0$; ura $3 \Delta 0$ ). Constructs cloned into plasmid pYX222 were transformed into S. cerevisiae strain 954 VW K70 (MAT his3 SUC2 GAL MAL 2-8c). Yeast transformants were initially grown on YNB agar plates lacking uracil or histidine to select for plasmid retention. For the TM6" Fps1 cultivations, $5 \mathrm{~mL}$ cultures were inoculated and grown for $72 \mathrm{~h}$ prior to being used to inoculate $50 \mathrm{~mL}$ cultures, which were grown for a period of $24 \mathrm{~h}$ and used to inoculate cultures in $2.5 \mathrm{~L}$ to a final $\mathrm{OD}_{610}$ of 0.05 . For the wild-type cultivations, $100 \mathrm{~mL}$ cultures were grown for $24 \mathrm{~h}$ before inoculating the bioreactors to a final $\mathrm{OD}_{610}$ of 0.05 . Yeast cells were cultured in $2.5 \mathrm{~L} 2 \times$ CBS medium [44], with $2 \%$ glucose as the sole carbon and energy source. For growth of TM6* with ethanol in the medium, $7 \mathrm{~g} \mathrm{~L}^{-1}$ ethanol were added to the bioreactor together with glucose just before the inoculation. The $\mathrm{pH}$ of the cultures was maintained at $\mathrm{pH} 5$ using $1 \mathrm{M}$ $\mathrm{NaOH}$. Polypropylene glycol P2000 was added as antifoam $\left(100 \mu \mathrm{L} \mathrm{L}^{-1}\right)$. Agitation and aeration of the cultures were set at $1000 \mathrm{rpm}$ and $0.5 \mathrm{vol} \mathrm{vol}^{-1} \mathrm{~min}^{-1}$, respectively whilst the temperature was set at either $20^{\circ} \mathrm{C}$ or $30^{\circ} \mathrm{C}$. The control of the $\mathrm{pH}$, agitation, aeration and temperature was maintained online. Gas evolution was monitored online (type $\mathrm{CP} 460 \mathrm{O}_{2} / \mathrm{CO}_{2}$, Belach Bioteknik $\mathrm{AB}$ ).

For glucose fed-batch cultivations, the wild-type $S$. cerevisiae strain $954 \mathrm{VW} \mathrm{K} 70$ was cultured at $30^{\circ} \mathrm{C}, \mathrm{pH} 5$. $100 \mathrm{~mL}$ cultures were grown for a period of $24 \mathrm{~h}$ and used to inoculate cultures in $2.5 \mathrm{~L}$ bioreactors to a final $\mathrm{OD}_{610}$ of 0.1 . Yeast cells were cultured in $2.0 \mathrm{~L}$ YNB medium (1.7 $\mathrm{g} \mathrm{L}^{-1} \mathrm{YNB}$ (Q-Biogene), $\left.5 \mathrm{~g} \mathrm{~L}^{-1}\left(\mathrm{NH}_{4}\right)_{2} \mathrm{SO}_{4}\right)$ with $1 \%$ glucose until glucose was depleted, and then grown with a feed of $500 \mathrm{~mL} 10 \%$ glucose at a flow rate of $20 \mathrm{~mL} \mathrm{~h}^{-1}$. Polypropylene glycol P2000 was added as antifoam (100 $\left.\mu \mathrm{L} \mathrm{L}^{-1}\right)$. Agitation of the cultures was set at $600 \mathrm{rpm}$ and airflow of $0.6 \mathrm{~L} \mathrm{~min}^{-1}$. All cultivations were at least duplicated. We have previously developed a series of simple functional in vivo assays for aquaporins in yeast [6] (and references therein), and hence were able to confirm that the Fps1 was active under these conditions. Fps1 activity in wild-type yeast was previously reported [21], and there were no indications of any differences in this study.

BY4741 or TM6* transformed with the GPCR constructs were initially grown on YNB plates lacking uracil to verify plasmid retention. Single colonies were then used to inoculate $50 \mathrm{~mL} 2 \times$ CBS medium and cultured for a period of 24-48 $\mathrm{h}$. These pre-cultures were then used to inoculate $500 \mathrm{~mL} 2 \times$ CBS medium in a bioreactor to a final $\mathrm{OD}_{610} \mathrm{~nm}$ of 0.05 and cultured until glucose 
depletion was detected using a Accu-Chek active glucose analyser (Roche diagnostics, UK) according to the manufacturer's instructions. Cells were harvested by centrifugation at $5,000 \times \mathrm{g}, 4^{\circ} \mathrm{C}, 5 \mathrm{~min}$.

BY4741 or TM6* transformed with the GFP construct were grown on YNB plates lacking uracil to verify plasmid retention. Single colonies were then used to inoculate $50 \mathrm{~mL}$ YNB medium and cultured for a period of 48 h. These seed cultures were then used to inoculate fresh $50 \mathrm{~mL} \mathrm{YNB}$ medium in shake-flasks containing 0 or 1 $\mathrm{mM} \mathrm{CuSO}_{4}$ to a final $\mathrm{OD}_{610}$ of 0.15 and cultured for a period of $24 \mathrm{~h}$. Cells were harvested by centrifugation at $5,000 \times \mathrm{g}, 4^{\circ} \mathrm{C}, 5 \mathrm{~min}$.

\section{Protein, cell dry weight and extracellular substrate determination}

Samples for optical density measurements were taken periodically to measure growth. For the wild-types and ethanol-phase TM6" cultures, additional samples for subsequent protein, dry weight, and extracellular substrate/ product analysis were taken out at early, mid and late glucose phase (1-3-Glc) corresponding to a glucose concentration of $1.5 \%, 1.0 \%$ and $0.8 \%$ respectively, $4-$ Glc (when the glucose is depleted), and 5-EtOH and 6-Stat during the ethanol and stationary phases, $6.5 \mathrm{~h}$, and $18.5 \mathrm{~h}$ after glucose depletion, respectively. The same procedure was performed for the $\mathrm{TM}^{*}$ * cultures but also at additional time points. Therefore Glc 1-3 correspond to glucose concentrations above $1.5 \%, 1.5-0.5 \%$ and below $0.5 \%$, respectively. 4-Glc corresponds to glucose exhaustion and the stationary phase samples, 5-Stat, for the TM6* cultures are samples taken at least $10 \mathrm{~h}$ after glucose exhaustion. For extracellular substrate analysis, samples $(2 \times 1 \mathrm{~mL})$ were collected, and the supernatant recovered by centrifugation $(13,000 \times \mathrm{g}$ for $1 \mathrm{~min})$ and stored at $20^{\circ} \mathrm{C}$ prior to analysis with Boehringer Mannheim $\mathrm{GmbH}$ kits (Food Diagnostics, Stenungsund, Sweden) according to the manufacturer's instructions. Dry weight calculations were performed by harvesting $2 \times 5 \mathrm{~mL}$ samples in pre-weighed, desiccated sample vials, and the cell pellet recovered by centrifugation at $5,000 \times \mathrm{g}$ for $5 \mathrm{~min}$, at $4^{\circ} \mathrm{C}$. The cells were subsequently washed twice with $5 \mathrm{~mL}$ icecold MilliQ water, and recovered by centrifugation, as above. The pellets were then dried for $24 \mathrm{~h}$ at $110^{\circ} \mathrm{C}$, and stored in a desiccator prior to being weighed. Samples for protein analysis $(1-4 \times 50 \mathrm{~mL})$ were harvested and the cell pellet recovered by centrifugation at $5,000 \times \mathrm{g}$ for $5 \mathrm{~min}$ at $4{ }^{\circ} \mathrm{C}$ and stored at $-20^{\circ} \mathrm{C}$.

\section{Membrane preparation and immunoblots}

Analysis of Fps1 protein yields were performed on both the total cellular extract and the total membrane fraction. Cells were suspended in $20 \mathrm{mM}$ Tris- $\mathrm{HCl}$ (pH 7.6), 100 $\mathrm{mM} \mathrm{NaCl}, 0.5 \mathrm{mM}$ EDTA, 5 \% glycerol and mixed with glass beads at a 1:1:1 ratio. The cells were agitated in a FastPrep (Q-Biogene) at a speed of $6.5,3 \times 20 \mathrm{~s}$ with a 60 $\mathrm{s}$ incubation on ice between the pulses. Unbroken cells were recovered by centrifugation at $500 \times \mathrm{g}$ for $10 \mathrm{~min}$ at $4^{\circ} \mathrm{C}$, and the supernatant further clarified at $10,000 \times \mathrm{g}$ for $30 \mathrm{~min}$ at $4^{\circ} \mathrm{C}$. The total membrane fraction was collected from this clarified supernatant by ultra-centrifugation at $100,000 \times \mathrm{g}$ for $90 \mathrm{~min}$ at $4^{\circ} \mathrm{C}$. The protein concentration was estimated using a BioRad Protein Assay Kit with bovine serum albumin as a standard. Immunoblotting was carried out with $35 \mu \mathrm{g}$ of crude cell extract and $75 \mu \mathrm{g}$ of total membrane fraction loaded on a $7.5 \%$ SDS polyacrylamide gel and separated at $65 \mathrm{~V}$ through the stacking gel and $140 \mathrm{~V}$ through the separating gel for approximately $1 \mathrm{~h}$. Proteins were transferred to a nitrocellulose membrane and blocked with PBS containing $5 \%$ milk for $1 \mathrm{~h}$ before being probed with a mouse monoclonal HA antibody $(1: 1,000)$ overnight in PBS containing $5 \%$ milk. After washing with PBS containing $5 \%$ milk the membrane was incubated with a secondary goat anti-mouse IgG HRP conjugated antibody $(1: 2,500)$ for 1 $\mathrm{h}$ in PBS containing $5 \%$ milk. The membrane was then washed in PBS containing $5 \%$ milk; followed by PBS containing $0.1 \%$ Tween-20 and finally with PBS. The blots were developed with an ECL Plus Western Blotting Detection Kit (Amersham Pharmacia) according to the manufacturer's instructions, visualised using the Image Reader LAS-100 (Fujifilm), and quantified using Multi Gauge 3.0 (Fujifilm). Either total extract or the membrane-bound fraction isolated from Sample 2 of a $30^{\circ} \mathrm{C}$, pH 5 wild-type culture [21] in YNB medium was used as an internal standard, which is the yield of Fps1 during the glucose growth phase of cells cultured at $30^{\circ} \mathrm{C}, \mathrm{pH} 5$ when the $\mathrm{OD}_{610}$ was 1.5-3.0 and residual glucose levels were 2-5 $\mathrm{g} / \mathrm{L}$. All signals were below saturation and related to the signal of the internal standard.

\section{Radioligand binding on wild-type and TM6* membranes containing recombinant human $A_{2 a} R$ and CNR2}

Cells were washed once with ice-cold breaking buffer (50 mM sodium phosphate buffer pH7.4, $100 \mathrm{mM} \mathrm{NaCl}, 5 \%$ glycerol, $2 \mathrm{mM}$ EDTA, $1 \mathrm{mM}$ PMSF) and suspended to 30 $\%$ wet weight. $0.5 \mathrm{~mm}$ glass beads were added to the cell suspension at a $1: 1$ ratio and cells broken at $4^{\circ} \mathrm{C}$ using a FastPrep24 cell disrupter (MP Biomedical) with 8 cycles of $30 \mathrm{~s}$ shaking and $30 \mathrm{~s}$ incubation on ice. Unbroken cells/cell debris were separated from the membrane suspension by centrifugation $\left(3000 \times \mathrm{g}, 5 \mathrm{~min}, 4^{\circ} \mathrm{C}\right)$. Total membranes were then recovered at 100,000 $\times \mathrm{g}, 45 \mathrm{~min}$, $4^{\circ} \mathrm{C}$ and suspended in membrane buffer $(50 \mathrm{mM}$ Tris $\mathrm{pH}$ 8.0, $120 \mathrm{mM} \mathrm{NaCl}, 20 \%$ glycerol, $1 \mathrm{mM}$ PMSF) using a dounce homogenizer. Membrane proteins were quantified following the BCA method (Pierce, Rockford, IL, 
USA), using BSA as a standard and snap frozen in liquid nitrogen prior to storage at $-80^{\circ} \mathrm{C}$.

Saturation ligand binding assays were performed for membranes containing human $\mathrm{A}_{2 \mathrm{a}} \mathrm{R}$ with $\left[{ }^{3} \mathrm{H}\right] \mathrm{ZM} 241385$ and ZM241385 $(10 \mu \mathrm{M})$ ligands in $50 \mathrm{mM}$ Tris $\mathrm{HCl} \mathrm{pH}$ 7.4, $1 \mathrm{mM}$ EDTA, $10 \mathrm{mM} \mathrm{MgCl}_{2}$, and incubated at $25^{\circ} \mathrm{C}$ for $1 \mathrm{~h}$. In the case of human CNR2, [ $\left.{ }^{3} \mathrm{H}\right] \mathrm{CP} 55940$ and CP55940 $(50 \mu \mathrm{M})$ in $50 \mathrm{mM}$ Tris $\mathrm{HCl} \mathrm{pH} \mathrm{7.4,} 2.5 \mathrm{mM}$ EDTA, $5 \mathrm{mM} \mathrm{MgCl}_{2}, 0.5 \mathrm{mg} \mathrm{ml}^{-1} \mathrm{BSA}$ were incubated at $30^{\circ} \mathrm{C}$ for $1.5 \mathrm{~h}$. For each experiment, $10 \mu \mathrm{g}$ of membrane protein were incubated in triplicate with increasing concentrations of radioligand until equilibrium was reached (total binding conditions). For non-specific binding determination, similar incubations were performed in parallel in the presence of an excess of unlabelled specific ligand. Bound and free ligands were separated by rapid filtration with Perkin-Elmer GF/B 96-unifilters presoaked in $0.3 \%$ polyethylenimine. The filters were washed 3 times and the retained radioactivity measured by liquid scintillation counting in a TopCount scintillation counter (Perkin Elmer). Saturation curves were analysed by nonlinear regression using Prism software (GraphPad Software, La Jolla, USA) to determine $B_{\max }$ and $K_{d}$ values.

\section{GFP determination in wild-type and TM6* strains}

Cells were suspended in $0.7 \mathrm{~mL}$ ice-cold breaking buffer (50 mM sodium phosphate buffer pH7.4, $100 \mathrm{mM} \mathrm{NaCl}$, $5 \%$ glycerol, $2 \mathrm{mM}$ EDTA) and glass beads added at a 1:1 ratio. Cells were disrupted in a FastPrep24 for 4 cycles of speed 6.5, $30 \mathrm{~s}$ with $2 \mathrm{~min}$ incubation on ice between cycles. Cell debris and unbroken cells were removed by centrifugation at $5,000 \times \mathrm{g}, 4^{\circ} \mathrm{C}$ for $3 \mathrm{~min}$ and the supernatant clarified and recovered at $20,000 \times \mathrm{g}, 4^{\circ} \mathrm{C}$ for 30 min. $150 \mu \mathrm{l}$ of supernatant was mixed with $50 \mu \mathrm{L} 1 \mathrm{M}$ potassium phosphate, $\mathrm{pH} 8.0$ and loaded in triplicate in black Nunc MaxiSorp 96-well plates. The fluorescence was determined on a SpectraMax Gemini XS plate reader (Molecular Devices, Wokingham, UK) with excitation and emission wavelengths of $390 \mathrm{~nm}$ and $510 \mathrm{~nm}$ respectively and a $495 \mathrm{~nm}$ cut-off.

\section{Competing interests}

The authors declare that they have no competing interests.

\section{Authors' contributions}

$\mathrm{CF}, \mathrm{NB}, \mathrm{KH}$ and $\mathrm{RD}$ were involved in all aspects of the experimental design, data collection, analysis and interpretation. CL and RW made the GPCR constructs and performed the ligand binding assays. $L G$ and $C L$ contributed to the data analysis and interpretation. RB directed the study, co-ordinated the data analysis and interpretation, and drafted the manuscript. All authors contributed to, read and approved the final version of the manuscript.

\section{Acknowledgements}

This work was supported by the European Commission via contracts LSHG-CT2004-504601 (E-MeP) and LSHG-CT-2006-037793 (OptiCryst) to RMB, and
QLG2-CT-2002-00988 (SPINE) to LG and RMB. The BBSRC supports bioreactors and a flow microcalorimeter in the RMB Laboratory through an REl award.

\section{Author Details}

${ }^{1}$ Chemical and Biological Engineering/Molecular Biotechnology, Chalmers University of Technology, 41296 Göteborg, Sweden, 2School of Life and Health Sciences, Aston University, Aston Triangle, Birmingham B4 7ET, UK, 3UMR 7175 - LC1, Dpt Récepteurs et Protéines Membranaires, ESBS, Blvd Sébastien Brant, BP 10413, 67412 Illkirch Cedex, France and ${ }^{4}$ Department of Chemistry/ Biochemistry, Göteborg University, Box 462, 40530 Göteborg, Sweden

Received: 10 March 2010 Accepted: 17 June 2010

Published: 17 June 2010

\section{References}

1. Grisshammer R, Tate C: Overexpression of integral membrane proteins for structural studies. Q Rev Biophys 1995, 3:315-422.

2. Miroux B, Walker JE: Over-production of proteins in Escherichia coli: mutant hosts that allow synthesis of some membrane proteins and globular proteins at high levels. J Mol Biol 1996, 260(3):289-298.

3. Ward A, Sanderson NM, O'Reilly J, Rutherford NG, Poolman B, Henderson PJF: Membrane Transport, a practical approach Edited by: Baldwin SA. New York: Oxford University Press; 2000:141-166.

4. Monne M, Chan KW, Slotboom DJ, Kunji ER: Functional expression of eukaryotic membrane proteins in Lactococcus lactis. Protein Sci 2005, 14(12):3048-3056.

5. Wagner S, Klepsch MM, Schlegel S, Appel A, Draheim R, Tarry M, Hogbom M, van Wijk KJ, Slotboom DJ, Persson JO, et al.: Tuning Escherichia coli for membrane protein overexpression. Proc Natl Acad Sci USA 2008, 105(38):14371-14376.

6. Bill RM: Yeast-a panacea for the structure-function analysis of membrane proteins? Curr Genet 2001, 40(3):157-171

7. Bosman GJ, van Oostrum J, Breikers G, Bovee-Geurts PH, Klaassen CH, DeGrip WJ: Functional expression of His-tagged rhodopsin in Sf9 insect cells. Methods Mol Biol 2003, 228:73-86.

8. Lundstrom K: Semliki Forest virus vectors for rapid and high-level expression of integral membrane proteins. Biochim Biophys Acta 2003, 1610(1):90-96.

9. Koglin A, Klammt C, Trbovic N, Schwarz D, Schneider B, Schafer B, Lohr F, Bernhard F, Dotsch V: Combination of cell-free expression and NMR spectroscopy as a new approach for structural investigation of membrane proteins. Magn Reson Chem 2006, 44(S1):17-23.

10. Heterologous Expression of Membrane Proteins: Methods and Protocols. Edited by: Mus-Veteau I. New York: Humana Press; 2010.

11. Sarramegna $V$, Talmont F, Demange P, Milon A: Heterologous expression of G-protein-coupled receptors: comparison of expression systems from the standpoint of large-scale production and purification. Cell Mol Life Sci 2003, 60(8):1529-1546.

12. Freigassner M, Pichler $H$, Glieder A: Tuning microbial hosts for membrane protein production. Microb Cell Fact 2009, 8:69.

13. Grisshammer R: Understanding recombinant expression of membrane proteins. Curr Opin Biotechnol 2006, 17(4):337-340

14. Wagner S, Bader ML, Drew D, de Gier JW: Rationalizing membrane protein overexpression. Trends Biotechnol 2006, 24(8):364-371.

15. Reilander $\mathrm{H}$, Weiss HM: Production of G-protein-coupled receptors in yeast. Curr Opin Biotechnol 1998, 9(5):510-517.

16. Gelperin DM, White MA, Wilkinson ML, Kon Y, Kung LA, Wise KJ, LopezHoyo N, Jiang L, Piccirillo S, Yu H, et al:: Biochemical and genetic analysis of the yeast proteome with a movable ORF collection. Genes Dev 2005, 19(23):2816-2826.

17. Jidenko M, Nielsen RC, Sorensen TL, Moller JV, le Maire M, Nissen P, Jaxel C: Crystallization of a mammalian membrane protein overexpressed in Saccharomyces cerevisiae. Proc Natl Acad Sci USA 2005, 102(33):11687-11691.

18. Long SB, Campbell EB, Mackinnon R: Crystal structure of a mammalian voltage-dependent Shaker family K+ channel. Science 2005, 309(5736):897-903

19. Tornroth-Horsefield S, Wang Y, Hedfalk K, Johanson U, Karlsson M Tajkhorshid E, Neutze R, Kjellbom P: Structural mechanism of plant aquaporin gating. Nature 2006, 439(7077):688-694 . 
20. Horsefield R, Norden K, Fellert M, Backmark A, Tornroth-Horsefield S, Terwisscha van Scheltinga AC, Kvassman J, Kjellbom P, Johanson U, Neutze R: High-resolution $x$-ray structure of human aquaporin 5. Proc Natl Acad Sci USA 2008, 105(36):13327-13332.

21. Bonander N, Hedfalk K, Larsson C, Mostad P, Chang C, Gustafsson L, Bill RM: Design of improved membrane protein production experiments: quantitation of the host response. Protein Sci 2005, 14(7):1729-1740.

22. Griffith DA, Delipala C, Leadsham J, Jarvis SM, Oesterhelt D: A novel yeast expression system for the overproduction of quality-controlled membrane proteins. FEBS Lett 2003, 553(1-2):45-50.

23. Bonander N, Darby RA, Grgic L, Bora N, Wen J, Brogna S, Poyner DR, O'Neill $M A$, Bill RM: Altering the ribosomal subunit ratio in yeast maximizes recombinant protein yield. Microb Cell Fact 2009, 8:10.

24. Cereghino JL, Cregg JM: Heterologous protein expression in the methylotrophic yeast Pichia pastoris. FEMS Microbiol Rev 2000, 24(1):45-66

25. Holmes WJ, Darby RA, Wilks MD, Smith R, Bill RM: Developing a scalable model of recombinant protein yield from Pichia pastoris: the influence of culture conditions, biomass and induction regime. Microb Cell Fact 2009, 8:35.

26. Singh S, Gras A, Fiez-Vandal C, Ruprecht J, Rana R, Martinez M, Strange PG, Wagner R, Byrne B: Large-scale functional expression of WT and truncated human adenosine A2A receptor in Pichia pastoris bioreactor cultures. Microb Cell Fact 2008, 7:28

27. Mattanovich D, Gasser B, Hohenblum H, Sauer M: Stress in recombinant protein producing yeasts. J Biotechnol 2004, 113(1-3):121-135.

28. Bill RM, Boles E, Gustafsson L, Hohmann S, Larsson C, Otterstedt K: Recombinant Saccharomyces cerevisiae Expressing Chimeric Glucose Transporters. WO0200880 2002

29. Otterstedt K, Larsson C, Bill RM, Stahlberg A, Boles E, Hohmann S, Gustafsson L: Switching the mode of metabolism in the yeast Saccharomyces cerevisiae. EMBO Rep 2004, 5(5):532-537.

30. Tamas MJ, Karlgren S, Bill RM, Hedfalk K, Allegri L, Ferreira M, Thevelein JM, Rydstrom J, Mullins JG, Hohmann S: A short regulatory domain restricts glycerol transport through yeast Fps1p. J Biol Chem 2003, 278(8):6337-6345

31. Hedfalk K, Bill RM, Mullins JG, Karlgren S, Filipsson C, Bergstrom J, Tamas MJ, Rydstrom J, Hohmann S: A regulatory domain in the C-terminal extension of the yeast glycerol channel Fps1p. J Biol Chem 2004, 279(15):14954-14960.

32. Cassland $\mathrm{P}$, Jonsson $\sqcup$ : Characterization of a gene encoding Trametes versicolor laccase $A$ and improved heterologous expression in Saccharomyces cerevisiae by decreased cultivation temperature. Appl Microbiol Biotechnol 1999, 52(3):393-400.

33. Sorensen HP, Mortensen KK: Soluble expression of recombinant proteins in the cytoplasm of Escherichia coli. Microb Cell Fact 2005 $4(1): 1$.

34. Lundstrom $\mathrm{K}$ : Structural genomics on membrane proteins: mini review. Comb Chem High Throughput Screen 2004, 7(5):431-439.

35. Andre N, Cherouati N, Prual C, Steffan T, Zeder-Lutz G, Magnin T, Pattus F, Michel H, Wagner R, Reinhart C: Enhancing functional production of $\mathrm{G}$ protein-coupled receptors in Pichia pastoris to levels required for structural studies via a single expression screen. Protein Sci 2006, 15(5):1115-1126.

36. Bill RM, Hedfalk K, Karlgren S, Mullins JG, Rydström J, Hohmann S: Analysis of the pore of the unusual major intrinsic protein channel, yeast Fps1p. J Biol Chem 2001, 276(39):36543-36549.

37. Karlgren S, Filipsson C, Mullins JG, Bill RM, Tamas MJ, Hohmann S: Identification of residues controlling transport through the yeast aquaglyceroporin Fps1 using a genetic screen. Eur J Biochem 2004, 271(4): $771-779$

38. Hedfalk K, Bill RM, Hohmann S, Rydström J: Overexpression and purification of the glycerol transport facilitators, Fps1p and GlpF in S. cerevisiae and E. coli. In Molecular Biology and Physiology of Water and Solute Transport: the MIP Family of Channel Proteins Edited by: Hohmann S, Nielsen S. New York: Kluwer/Plenum; 2000:p29-34.

39. Henricsson C, de Jesus Ferreira MC, Hedfalk K, Elbing K, Larsson C, Bill RM, Norbeck J, Hohmann S, Gustafsson L: Engineering of a novel Saccharomyces cerevisiae wine strain with a respiratory phenotype at high external glucose concentrations. Appl Environ Microbiol 2005, 71(10):6185-6192.
40. Bonander N, Ferndahl C, Mostad P, Wilks MD, Chang C, Showe L, Gustafsson L, Larsson C, Bill RM: Transcriptome analysis of a respiratory Saccharomyces cerevisiae strain suggests the expression of its phenotype is glucose insensitive and predominantly controlled by Hap4, Cat8 and Mig1. BMC Genomics 2008, 9:365.

41. Bonander N, Bill RM: Relieving the first bottleneck in the drug discovery pipeline: using array technologies to rationalise membrane protein production. Expert Rev Proteomics 2009, 6:501-505.

42. Elbing K, Stahlberg A, Hohmann S, Gustafsson L: Transcriptional responses to glucose at different glycolytic rates in Saccharomyces cerevisiae. Eur J Biochem 2004, 271(23-24):4855-4864.

43. Dijken JPv, Bauer J, Brambilla L, Duboc P, Francois JM, Gancedo C, Giuseppin MLF, Heijnen JJ, Hoare M, Lange HC, et al:: An interlaboratory comparison of physiological and genetic properties of four Saccharomyces cerevisiae strains. Enz Microb Technol 2000, 26:706-714.

44. Verduyn C, Postma E, Scheffers WA, Van Dijken JP: Effect of benzoic acid on metabolic fluxes in yeasts: a continuous-culture study on the regulation of respiration and alcoholic fermentation. Yeast 1992, 8(7):501-517.

doi: $10.1186 / 1475-2859-9-47$

Cite this article as: Ferndahl et al., Increasing cell biomass in Saccharomyces cerevisiae increases recombinant protein yield: the use of a respiratory strain as a microbial cell factory Microbial Cell Factories 2010, 9:47

\section{Submit your next manuscript to BioMed Central and take full advantage of:}

- Convenient online submission

- Thorough peer review

- No space constraints or color figure charges

- Immediate publication on acceptance

- Inclusion in PubMed, CAS, Scopus and Google Scholar

- Research which is freely available for redistribution

Submit your manuscript at www.biomedcentral.com/submit
C) Biomed Central 